
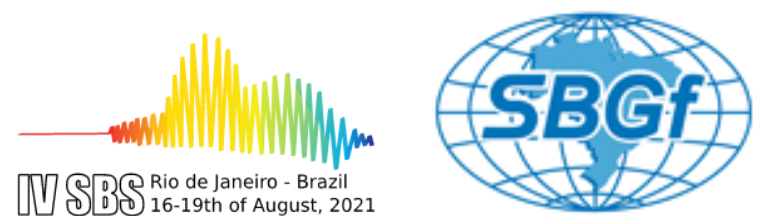

\title{
Successful experiences in coping with earthquakes in the State of Ceará
}

Francisco das Chagas Brandão Melo 1, Lucas Vieira Barros ${ }^{2}$, Brandow Lee Neri², 1 Coordenadoria Estadual de Proteção e Defesa Civil do Estado do Ceará, ${ }^{2}$ Universidade de Brasília - UnB

Copyright 2021, SBGf - Sociedade Brasileira de Geofísica.

This paper was prepared for presentation during the $17^{\text {th }}$ International Congress of the Brazilian Geophysical Society held in Rio de Janeiro, Brazil, $16-19$ August 2021.

Contents of this paper were reviewed by the Technical Committee of the $17^{\text {th }}$ International Congress of the Brazilian Geophysical Society and do not necessarily represent any position of the SBGf, its officers or members. Electronic reproduction or storage of any part of this paper for commercial purposes without the written consent of the Brazilian Geophysical Society is prohibited.

This work presents a synthesis of what was the disaster caused by the earthquake of Pacajus - CE, on November 20,1980, showing its consequences, and what lessons were learned for the evolution of knowledge and mitigation of the effects of future earthquakes. Forty years ago there was the biggest earthquake in the Northeast Region, the "PACAJUS EARTHQUAKE", raising a series of concerns regarding the protection of the communities affected by this recurring phenomenon in our state. To this end, mitigating measures have been implemented throughout this time, such as preventive actions, research, studies and debates with the affected communities, largely because of the magnitude and intensity of the event and the consequences of its impact. Not only in the epicentral area, but also in nearby areas in line with its repercussions. In this article as well, we seek to show the nuances related to coping with disasters not only in seismology but also the dynamics of living together with them. In this sense, we seek to show the actions on which good civil defense practices are based and founded. It is not by chance, but the main and first civil defense action becomes essential for any type of protection of the community. Prevention, as the name says: it is prevented, since it is based on the principle that the threat already exists and it has to be worked intending to safeguard lives. In this sense, we present our major product inducing good practices, recommended for living with earthquakes. This is the new seismology folder for the civil defense of the State of Ceará. In it, we tell the story of the earthquakes in Ceará, replicating actions already adopted in several campaigns in Ceará territory, or which could also be worked on mitigating the effects of this phenomenon. On the map, we show that, of the 184 (one hundred and eighty-four) municipalities in the State of Ceará, 62 (sixty-two) have already presented some type of seismicity of different magnitudes and different intensities. 